\title{
Market Entry and Foreign Direct Investment
}

\author{
Frank Stähler ${ }^{1}$
}

${ }^{1}$ Department of Economics, University of Kiel, Wilhelm-Seelig-Platz 1, D-24098 Kiel, Germany, email: fstaehler@econ-theory.uni-kiel.de 


\begin{abstract}
This paper discusses the impact of foreign direct investment (FDI) on market entry and welfare. It assumes that firms may enter markets in the first period as national firms only. In the second period, however, FDI is possible. The paper demonstrates that FDI reduces market entry because equilibrium profits in the second period decline with a decrease in the fixed cost of FDI. Therefore, compared to a trade regime without any FDI, prices rise in the first period but decline in the second period. The paper shows, however, that FDI will unambiguously improve the discounted sum of consumer surplus.
\end{abstract}

JEL-Classification: F12, F15.

Keywords: Foreign direct investment, multinational enterprises, imperfect competition, free entry. 


\section{Introduction}

This paper discusses the impact of foreign direct investment (FDI) on market structure and welfare in a two period model in which national firms may enter an international market in the first period and - once they have entered decide on FDI in the second period. The paper shows that equilibria are possible in which both national and multinational firms are active. If both types of firms coexist or if only multinational firms are active in the second period, the paper finds that FDI will reduce the number of entering firms in the first period because entering firms anticipate that competition in the second period will be the tougher the more multinational enterprises will then be active. The decrease in entering national firms increases equilibrium prices in the first period, but FDI decreases the equilibrium price in the second period. Compared with a trade regime under which FDI is banned, FDI will thus lead to welfare losses in the first period but to welfare gains in the second period. If consumers use the same discount factor as firms, the paper shows that FDI unambiguously improves the discounted sum of consumer surplus.

The paper is motivated by the fact that the welfare effects of FDI are not exhaustively understood compared to the welfare effects of trade although FDI seems to be more the driving force of globalization than trade. ${ }^{1}$ An exemption is De Santis and Stähler (2002) who show that FDI is welfare improving compared to trade if national and multinational firms may locate in each country. However, they also demonstrate that coexistence of national and multinational firms is not possible if countries are symmetric. Other papers on FDI and trade like Markusen and Veneable $(1998,2000)$ use a similar

\footnotetext{
${ }^{1}$ The literature distinguishes between horizontal FDI, that is, a firm sets up a further plant in the foreign country and keeps the plant in the home country running (Markusen, 1984; Horstmann and Markusen, 1992; Brainard, 1993; Markusen and Venables 1998, 2000) and vertical FDI, where the home plant is shut down instead (Helpman, 1984; Helpman and Krugman, 1985). The motive for horizontal FDI is to avoid trade costs, whereas the motive for vertical FDI is to exploit differences in factor prices and endowment. Empirical evidence suggests that FDI is dominantly of the first type (Brainard, 1997; Blonigen, 2001; Markusen, 1998, Markusen and Maskus, 2001) because most of the world-wide FDI takes place among industrialized countries which do not differ substantially.
} 
model structure but in a general equilibrium setting. They solve their model by numerical simulations and show that coexistence may ocur if countries are asymmetric.

This paper uses a similar approach as Horstmann and Markusen (1992) and De Santis and Stähler (2002) to model horizontal FDI. The difference to De Santis and Stähler (2002) is that a firm cannot enter a new market as a multinational firm right from the beginning because these coordination and monitoring costs are prohibitively large. However, once they have entered, they may decide on FDI in the future. In this setting, coexistence of both types of firms is possible in equilibrium. Accordingly, the paper is organized as follows: Section 2 will introduce the model and the structure of moves. Section 3 will determine the equilibrium market structure. Section 4 will present the impact of FDI on welfare. Section 5 will conclude.

\section{The model}

The model assumes two symmetric countries, a domestic country $d$ and a foreign country $f$, and two goods $X$ and $Y$. $Y$ is produced under perfect competition and is the numeraire of the model. $X$ is produced under imperfect competition, either by national firms or by multinational firms. There is only one factor of production, $L$, which is normalized such than one unit of $L$ produces one unit of $Y$. The quasi-linear preferences of the representative consumer are given by the utility function $U(X, Y)=a X-b X^{2} / 2+Y$ which is maximized subject to the budget constraint $L+\Pi \geq p X+Y$, where $\Pi$ denotes the profits realized by firms having their headquarters within the country of the representative consumer. $p$ denotes the price of $X$ in terms of the numeraire. Maximization yields the inverse demand function $p=a-b X$ for each country. Markets are assumed to be segmented but our results will also hold for integrated markets as long as firms may distinguish between production for the home market and production for the foreign market.

The marginal cost of production of good $X$ is $c$, and shipping this good from one country to the other has trade cost $t$ per unit. $K$ will denote the number of active firms in both countries. As usual in the trade literature, 
we will refer to those firms which serve the foreign market via exports as national firms, and to those which serve the foreign market by a plant set up in the foreign country as multinational firms. Multinational firms save the trade costs $t$ as they serve the foreign country with a plant set up in this country but they have to sink fixed cost for establishing the subsidiary by FDI. This paper assumes that multinational firms are not established immediately but that they have entered the market as national firms in the past. The reason is that setting up headquarters and starting the production process in one country alone is such challenging that the management is not able to establish simultaneously a subsidiary in the other country. Thus, the model assumes that foreign direct investment is possible only after a firm has already entered the market as a national firm. In particular, we assume the following sequence of decisions:

\section{- Period 1}

- Firms decide on market entry. If a firm enters the markets, it sinks $\operatorname{cost} F$ for setting up headquarters and one production plant in the home country.

- Each firm decides on output for the home market and exports.

\section{- Period 2}

- Each firm decides on (horizontal) foreign direct investment. If a firm becomes multinational, it sinks cost $G$ for setting up one production plant in the host country.

- Each firm decides on output for the home market and output for the foreign market.

From the viewpoint of period 1, the possibility of FDI in the second period is an uncertain option so that $G$ gives the expected cost to save trade costs by establishing a subsidiary. The profitability of FDI will depend on the size of $G$, and it is then clear that FDI will be the more attractive the lower 
the expected $G$ is. A reduction in the cost $G$ will therefore be treated as an exogenous shift which makes FDI potentially more attractive.

The game structure does not allow market entry in period 2. However, this assumption is less restrictive as it seems at first glance. The results do not change if the model assumed that - once national and multinational firms have been established - new firms may enter the market in a third period, either as national or multinational firms. The reason could be that the business has already reached a certain degree of maturity in period 3 so that simultaneously establishing a firm and a subsidiary is possible. The potential market entry of firms in subsequent periods would then change the profitability to enter the market in the first period but would affect all active firms, irrespective of their type. If these effects were to be taken into account, the discounted profits of further periods had be subtracted from the cost to enter the market, $F$, without changing the basic results. Hence, the game structure relies only upon the reasonable assumption that a new market can be explored only by national firms in a first step which then have a first mover advantage to establish subsidiaries before further multinational firms may be established.

The decision on market entry will rest upon the profits to be expected in these two period. In the first period, firms may enter only as national firms. If they enter, the first period profits of a domestic national firm are

$$
\Pi_{1}=\left(p_{1}^{d}-c\right) x_{1}^{d}+\left(p_{1}^{f}-c-t\right) x_{1}^{f}-F .
$$

The subscript 1 denotes period $1, p_{1}^{d}\left(p_{1}^{f}\right)$ denotes the first period price in the domestic (foreign) country and $x_{1}^{d}\left(x_{1}^{f}\right)$ denotes firm output for the domestic market (firm exports to the foreign market). If no second period existed, the model would coincide with the reciprocal dumping model of Brander (1981) and Brander, Krugman (1983).

In the second period, the cost $F$ are sunk and of no further relevance. But those firms which have entered the market will then decide on FDI. If a domestic firm decides to remain a national firm, denoted by the superscript $n$, its second period profits are 


$$
\Pi_{2}^{n}=\left(p_{2}^{d}-c\right) x_{2}^{n d}+\left(p_{2}^{f}-c-t\right) x_{2}^{n f}
$$

where the notation is similar to those used in eq. (1). In period 2, however, the firm may also decide to become multinational in order to save trade costs by making an investment with cost $G$. If a domestic firm goes for FDI, its second period profits are

$$
\Pi_{2}^{m}=\left(p_{2}^{d}-c\right) x_{2}^{m d}+\left(p_{2}^{f}-c\right) x_{2}^{m f}-G .
$$

The superscript $m$ denotes the multinational firm. Note that $x_{2}^{m f}$ does not denote exports but the production for the foreign market by a plant set up in the foreign country. In the remainder of the paper, $M$ will denote the number of multinational firms in both countries, for which $0 \leq M \leq K$, and hence $K-M$ is the number of national firms in both countries. Since both countries are symmetric, the number of active national and multinational firms in each country is $M / 2$ and $(K-M) / 2$, respectively. The subsequent section will determine the equilibrium number of firms.

\section{Endogenous market structures under trade and FDI}

This section will begin with analyzing the equilibrium market structure in period 2. In period 2, market entry is not possible but firms may be of national or multinational type. Solving for the f.o.c.'s of (2) and (3) determines the maximized profits of national and multinational firms which yield the following lemma.

Lemma 1 If market entry has occurred in period 1, national firms and multinational firms may coexist in period 2.

Proof: If both types of firms coexist, the second period profits will be equalized in equilibrium. Otherwise, a single firm has an incentive to switch its type unilaterally. Equalizing profits yields 


$$
\frac{(a-c+0.5 t(K-M))^{2}}{b(K+1)^{2}}-G=\frac{(a-c-t-0.5 t(K-M)-t M)^{2}}{b(K+1)^{2}}
$$

where the term on the LHS (RHS) of eq. (4) gives the profits of a multinational (national) firm. As $K$ is given, the equilibrium number of multinational firms is

$$
M^{*}=\frac{t(2(a-c)-t)-b G(K+1)}{t^{2}} .
$$

Obviously, the larger $G$, the lower will $M$ be. In particular, no multinational firm will be established, that is, $M^{*}=0$, if $G$ is equal to

$$
\bar{G}=\frac{t(2(a-c)-t)}{b(K+1)} .
$$

No firm will remain to be of the national type, that is, $M^{*}=K$, if $G$ is equal to

$$
\underline{G}=\frac{t(2(a-c)-(K+1) t)}{b(K+1)} .
$$

The proof for possible coexistence is complete if $G$ may lie between these two bounds which is in fact possible:

$$
\bar{G}-\underline{G}=\frac{K t^{2}}{b(K+1)}>0 .
$$

Note that the range $\bar{G}-\underline{G}$ is the larger the lower $K$ is. The reason is that multinational firms have to cover more fixed costs, and hence they have to be larger in terms of aggregate output than national firms. In particular, they produce more for the foreign market via the plant set up in the host country than they would export as a national firm. However, if the market is already crowded with a lot of rivals, a multinational can hardly be that profitable because it has to compete also with foreign national firms in the foreign country which are not at a cost disadvantage.

As it seems to be reasonable to consider the cases in which national and multinational firms coexist, the remainder of the paper assumes that 
$G$ is sufficiently large so that not only mulitnational firms will be active in period 2 .

Assumption $1 G \geq \underline{G}$.

Assumption 1 guarantees that both types of firms coexist as long as $G \leq \bar{G}$. In this case, the equilibrium profits of both the national and the multinational firm can be computed by inserting (5) into the LHS (or the RHS) of eq. (4):

$$
\Pi_{2}=\frac{b^{2} G^{2}+t^{2}}{2 b t^{2}}
$$

Firms deciding on market entry in the first period will correctly anticipate these equilibrium profits of period 2. Note carefully that the equilibrium profits decrease with the expected fixed cost $G$ to become a multinational firm. In other words, the less profitable FDI is, the larger are the second period equilibrium profits. The reason is a business stealing effect which makes all firm suffer from FDI. All firms would prefer to remain national firms, but a single firm has an incentive to defect since it is able to increase its profits unilaterally. If a single firm has an incentive to become multinational, it will expand output for the foreign market and will thus reduce the profits of national firms. However, further multinational firms will then be established until profits are equalized. ${ }^{2}$ Therefore, profits will be reduced for both types of firms compared to the case that all firms remained national firm.

The market entry decision in period 1 will also depend on the equilibrium profits in period 1. Since only national firms will be active then, using the f.o.c.'s of the maximization exercise concerning (1) leads to profits of

$$
\Pi_{1}=\frac{(a-c+0.5 t K)^{2}}{b(K+1)^{2}}+\frac{(a-c-t-0.5 t K)^{2}}{b(K+1)^{2}}-F .
$$

The range of $F$ should be restricted such that

\footnotetext{
${ }^{2}$ This effect can also be observed from (1) because both the LHS of (1), that is, the profits of a multinational firm, and the RHS of (1), that is, the profits of a national firm, decrease with $M$.
} 


\section{Assumption 2}

$$
\frac{b^{2} \delta G^{2}+(1+\delta) t^{4}}{2 b t^{2}}<F<\frac{b^{2} \delta G^{2}+(1+\delta) t^{4}}{2 b t^{2}}+\frac{2(a-c)(a-c-2 t)+t^{2}}{2 b}
$$

holds which will ensure a feasible solution. Market entry occurs until the discounted sum of expected profits over both periods is zero, that is

$$
\Pi_{1}+\delta \Pi_{2}=0, \quad 0<\delta<1,
$$

where $\delta$ denotes the (common) discount factor by which firms take the second period profits into account in period 1. Eq. (11) allows to discuss the impact of FDI on market structure.

Proposition 1 The equilibrium number of active firms decreases with the cost of foreign direct investment.

Proof: Under the use of (10) and (11), the equilibrium number of firms entering the markets in period 1 is

$$
K^{*}=\frac{(a-c)+(a-c-t)}{\sqrt{2 b\left(F-\delta \Pi_{2}\right)-t^{2}}}-1 .
$$

Since $\Pi_{2}$ depends positively upon $G$ (see $\left.(9)\right), K^{*}$ decreases with $G$. Assumption 2 guarantees that $0<K^{*}<\infty$.

Proposition 1 shows that FDI leads to less market entry because firms anticipate that FDI leads to more competition in the future. Thus, market concentration occurs. Under the use of $K^{*}$, multinational firms will become active in the second period if the fixed cost of foreign direct investment is less than

$$
\bar{G}=\frac{t \sqrt{2 b F-(1+\delta) t^{2}}}{b \sqrt{1+\delta}} .
$$

\section{Welfare results}

This section will now explore how FDI will change welfare. The reference point for the comparison is a pure trade regime under which FDI is not 
possible, for instance because capital controls effectively ban FDI. Then, the FDI ban is lifted, and firms may become multinational in the second period. Analytically, the welfare effects will be explored by considering a reduction in the fixed cost of foreign direct investment, $G$. This can be best understood as taking $\bar{G}$ as the starting point for which FDI will not occur. Then, the expected fixed cost of FDI is reduced and the change in welfare with this reduction can be determined. Furthermore, this section will assume that the discount factor used by firms coincides with the discount factors used by the representative consumer and any social planner. Then, as firms will enter in the first period until the discounted sum of profits is equal to zero, only the impact of FDI on consumer surplus matters. The first result shows that FDI does not unambiguously change welfare in both periods.

Proposition 2 If an FDI-trade regime replace a pure trade regime, prices rise in the first period but decline in the second period.

Proof: The f.o.c.'s for (1), (2) and (3) and the equilibrium values for $M$ and $K$ (see (5) and (12)) allow to compute the aggregate output in each market for each period, that is,

$$
\begin{gathered}
X_{1}=\frac{2(a-c)-t-\sqrt{2 b F-t^{2}-2 \delta b \Pi_{2}}}{2 b}, \\
X_{2}=\frac{2(a-c)-t-\frac{b G}{t}}{2 b},
\end{gathered}
$$

and the equilibrium prices in each market in each period, that is,

$$
\begin{gathered}
p_{1}=c+\frac{t+\sqrt{2 b\left(F-\delta \Pi_{2}\right)-t^{2}}}{2} \\
p_{2}=c+\frac{b G+t^{2}}{2 t}
\end{gathered}
$$

As $\Pi_{2}$ depends positively upon $G$ (see 9 ), $p_{1}$ decreases with $G$. The effect on $p_{2}$ is obvious from (17).

Since consumer surplus is negatively related to prices, Proposition 2 shows that FDI will reduce the first period welfare but will increase the second period welfare. The possibility to make an FDI lets firms anticipate the business 
stealing effect in the second period. This business stealing effect reduces the second period equilibrium profits, and hence less firms will enter in the first period. Consequently, market concentration implies higher prices. In the second period, however, the business stealing effect is beneficial for consumers, because multinationals increase aggregate production and thus reduce prices. As the impact on welfare is not unambiguous for each period, the next result demonstrates the aggregate welfare effect over both periods.

Proposition 3 Foreign direct investment unambiguously improves the discounted sum of consumer surplus.

Proof: Due to the quasi-linear preferences, the discounted sum of consumer surplus is equal to

$$
C S=\frac{b X_{1}^{2}}{2}+\delta \frac{b X_{2}^{2}}{2} .
$$

Under the use of (14) and (15), differentiation of $C S$ with respect to $G$ yields

$$
\frac{d C S}{d G}=\gamma(G) \frac{2(a-c)-t}{4 t^{2} \sqrt{2 b F-\frac{\delta b^{2} G^{2}}{t^{2}}-(1+\delta) t^{2}}}
$$

with

$$
\gamma(G)=b G-t \sqrt{2 b F-\frac{\delta b^{2} G^{2}}{t^{2}}-(1+\delta) t^{2}}
$$

Note that the root in the denominator is unambiguously positive due to Assumption $2\left(K^{*}<\infty\right.$ requires $2 b F-\frac{\delta b^{2} G^{2}}{t^{2}}-(1+\delta) t^{2}$ if $\Pi_{2}$ is replaced by (9) in (12)). Therefore, the sign of $d C S / d G$ depends on $\gamma(G)$. If $\gamma(G)$ is negative, the change of $C S$ with $G$ is negative. Note that

$$
\gamma^{\prime}=b+\frac{\delta b^{2} G}{t \sqrt{2 b F-\frac{\delta b^{2} G^{2}}{t^{2}}-(1+\delta) t^{2}}}>0 .
$$

Furthermore

$$
\gamma(\bar{G})=0 .
$$


Hence, $\gamma$ is negative if multinational firms are active, and thus $C S$ decreases with $G$.

Proposition 3 demonstrates that the decrease in the first period consumer surplus is outnumbered by the increase in the second period consumer surplus. This is a remarkable result because it shows that welfare will rise despite the fact that FDI will lead to market concentration and higher prices in the first period.

\section{Concluding remarks}

This paper has set up a model in which firms start their business as exporting, that is, national firms and may become multinational later on. It has demonstrated that coexistence of national and multinational firms is then possible. Furthermore, it has shown that FDI may lead to less entry into new markets compared to a trade regime under which FDI is banned. The option of FDI in future periods reduces the profits of firms as competition will be tougher then, and this effect is anticipated by potentially entering firms. As a result, prices will rise in the first period, but will decline in future periods compared to a pure trade regime. Although welfare thus declines today but rises tomorrow, the paper has shown that FDI unambiguously improves the discounted sum of consumer surplus and hence welfare as profits are zero in equilibrium.

The paper has demonstrated that this two period model can partially confirm the public concerns about possible market concentration as a result of the emergence of multinational firms. It has shown this result in a setting in which multinational firms cannot compete with national firms when new markets are explored. It is true that the future option of FDI will unambiguously lead to market concentration and less consumer surplus today. However, these effects are only the first part of the story. In the future, consumers benefit from multinational enterprises as this type of firms will be closer to the markets compared to exporting firms and competition will be tougher. The paper has shown that allowing FDI and reducing welfare today may pay off because the future welfare increase is larger than the recent 
welfare loss.

\section{References}

Blonigen, B.A. (2001), In search of substitution between foreign production and exports, Journal of International Economics, 53: 81-104.

Brainard, S.L. (1993), 'A simple theory of multinational corporations and trade with a trade-off between proximity and concentration', NBER Working Paper, n. 4269.

Brainard, S. L. (1997), 'An empirical assessment of the proximityconcentration trade-off between multinational sales and trade', American Economic Review, 87: 520-540.

Brander, J.A. (1981), 'Intra-industry trade in identical commodities', Journal of International Economics, 11: 1-14.

Brander, J.A., Krugman, P.R. (1983), 'A "reciprocal dumping" model of international trade', Journal of International Economics, 15: 313-323.

De Santis, R., Stähler, F. (2002), 'Endogenous market structures and the gains from foreign direct investment', mimeo.

Dunning, J.H. (1977), 'Trade, location of economic activity and MNE: A search for an eclectic approach', in Ohlin, B., Hesselborn, P.O., Wijkman, P.M. (eds.), The International Allocation of Economic Activity, London, Macmillan.

Helpman, E. (1984), 'A simple theory of trade with multinational corporations', Journal of Political Economy, 92: 451-571.

Helpman, E., Krugman, P.R. (1985), Market Structure and Foreign Trade, MIT Press, Cambridge.

Horstmann, I.J., Markusen, J.R. (1992), 'Endogenous market structures in international trade (natura facit saltum)', Journal of International Economics, 32: 109-129. 
Markusen, J.R. (1984), 'Multinationals, multi-plant economies, and the gains from trade', Journal of International Economics, 16: 205-226.

Markusen, J.R. (1998), 'Multinational firms, location and trade', World Economy, 21: 733-756.

Markusen, J.R., Maskus, K.E. (2001), 'Discriminating among alternative theories of the multinational enterprise', in: M. Blomstrom, L. Goldberg (eds.), Topics in Empirical International Economics, Chicago University Press, Chicago.

Markusen, J.R., Venables, A.J. (1998), 'Multinational firms and the new trade theory', Journal of International Economics, 46: 183-203.

Markusen, J.R. and Venables, A.J. (2000), The theory of endowment, intraindustry, and multinational trade, Journal of International Economics, 52: 209-234. 